\title{
The Effect of Interactive Multimedia Base Problem Solving on Students' Critical Thinking Skills in Equilibrium and Rotational Dynamics Concept
}

\author{
Sri Ratnaningsih ${ }^{1}$, Erina Hertanti ${ }^{2}$ \\ \{ sri.ratnaningsih14@mhs.uinjkt.ac.id ${ }^{1}$, erina.hertanti@uinjkt.ac.id $\left.{ }^{2}\right\}$
}

${ }^{1,2}$ UIN Syarif Hidayatullah Jakarta, Indonesia

\begin{abstract}
The main problem of this study is physics learning process has not involved activity that can train critical thinking skill, so that affects students' critical thinking skill low. This study aims to determine the effect of interactive multimedia base problem solving on students' critical thinking skills in equilibrium and rotational dynamics concept. The study was conducted at Al-Qur'aniyyah Integrated Islamic Senior High School on July 2019. Purposive sampling was used in order to determine the samples of the test. This study used quasi-experimental method as research methodology and nonequivalent control group research design. The study used essay questions as instrumental test and questionnaire as instrumental non test. The hypothesis test of posttest score showed that there is an effect of interactive multimedia base problem solving on students' critical thinking skills. Meanwhile, the result of students' questionnaire shows that learning using interactive multimedia base problem solving got a good category $(78 \%)$.
\end{abstract}

Keywords: critical thinking, interactive, multimedia, problem solving, skill

\section{Introduction}

The equilibrium and rotational dynamics are physics concept concerned with the study of motion and object rotation. Rolling object, seesaw, and the dancer that do the spinning are example of equilibrium and rotational dynamics concept. This means that this concept related to the problem of daily life. Moreover, this concepts are complex and abstract [1]. Accordingly, learning equilibrium and rotational dynamics concept needs some thinking skills, such as critical thinking skill.

Critical thinking is reflective and reasonable thinking that is focused on deciding what to believe and do [2]. This means while someone does critical thinking skill optimally, they will make wise decision in their every lives [3]. However, there are obstacles to form students' critical thinking skill. First, physics learning process is dominated by conventional learning, so that students tend to be passive and lack of building their critical thinking skills. Second, students are only able to answer questions regarding of students' remembering and understanding aspect and almost never drilled to apply critical thinking method to solve problem [4]. These two obstacles cause students' critical thinking low. Hence, it is needed learning tools to facilitate students to form their critical thinking. Also, this research uses interactive multimedia as the tool.

Interactive multimedia is the unification of some media (audio, video, text, or graphic) that empowering the user to control the environment usually by the computer [5] [6]. Interactive multimedia enable learning process focusing on students and guiding to do the 
exploration, inquiry, and solving problem. However, nowadays, interactive multimedia could not make students to solve problem optimally [7]. Whereas problem solving can enhance students' critical thinking skill [8] [9]. The most common interactive multimedia only contain materials, experimental videos, and evaluation tests that do not support students to build their critical thinking. By this conclusion, interactive multimedia that are being applied to enhance critical thinking skills in this research is interactive multimedia base problem solving. This multimedia is considered can enhance students' critical thinking skill.

\section{Method}

The research is conducted at Al-Qur'aniyyah Integrated Islamic Senior High School on July 2019. The research method is quasi-experimental research with nonequivalent controlled group design. This design is divided into the controlled and the experimental group [10] [11]. Population in this research are students of Al-Qur'aniyyah Integrated Islamic Senior High School, while the samples are 11 Nature Science 2 (experimental class) and 11 Nature Science 1 (controlled class). Data are collected by two techniques, they are test and nontest. The tests are giving pretest and posttest to experimental class and controlled class to know the critical thinking skill before and after doing the research. The test is 12 essay question of critical thinking skill by Robert H. Ennis. It consists of the elementary clasification; the basic support; inference; advanced classification; the strategies and tactics [12]. The nontest is giving the questionnaire to experimental class to know the response while they are being given the treatment by using interactive multimedia base problem solving. Last, the data are analyzed by using Statictical Product and Service Solution (SPSS).

The interactive multimedia not only contain materials, experimental videos, and evaluation tests. This interactive multimedia is developed based on very familiar design, Polya problem solving indicator witch consist of understanding the problem (understanding), devising plan (planning), carrying out the plan (solving), and looking back the problem (checking) [13]. This design is considered can make students active to solve problem so that it can enhance their critical thinking skill.

\section{Result and Discussion}

\subsection{Result}

The result of pretest and posttest from experimental class and controlled class can be seen on Table 1. According to Table 1, both of experimental class and controlled class develope the average value by giving the different treatment.

Table 1. Pretest And Posttest Recapitulation Experimental class and Controlled class

\begin{tabular}{ccccc}
\hline \multirow{2}{*}{ Data } & \multicolumn{2}{c}{ Prestest Score } & \multicolumn{2}{c}{ Posttest Score } \\
\cline { 2 - 5 } & $\begin{array}{c}\text { Experimental } \\
\text { class }\end{array}$ & $\begin{array}{c}\text { Control } \\
\text { class }\end{array}$ & $\begin{array}{c}\text { Experimental } \\
\text { class }\end{array}$ & $\begin{array}{c}\text { Control } \\
\text { class }\end{array}$ \\
\hline The lowest score & 7,00 & 17,00 & 35,00 & 35,00 \\
The highest score & 37,00 & 47,00 & 80,00 & 80,00 \\
Average & 24,81 & 26,35 & 60,04 & 49,35 \\
Modus & 20,00 & 28,00 & 52,00 & 47,00 \\
Median & 27,00 & 27,00 & 62,50 & 47,00 \\
Stand. Deviation & 6,69 & 6,24 & 13,75 & 9,54 \\
\hline
\end{tabular}


In addition, analysis data of experimental class and controlled class pretest and posttest based on critical thinking skill categories can be seen on the Figure 1.

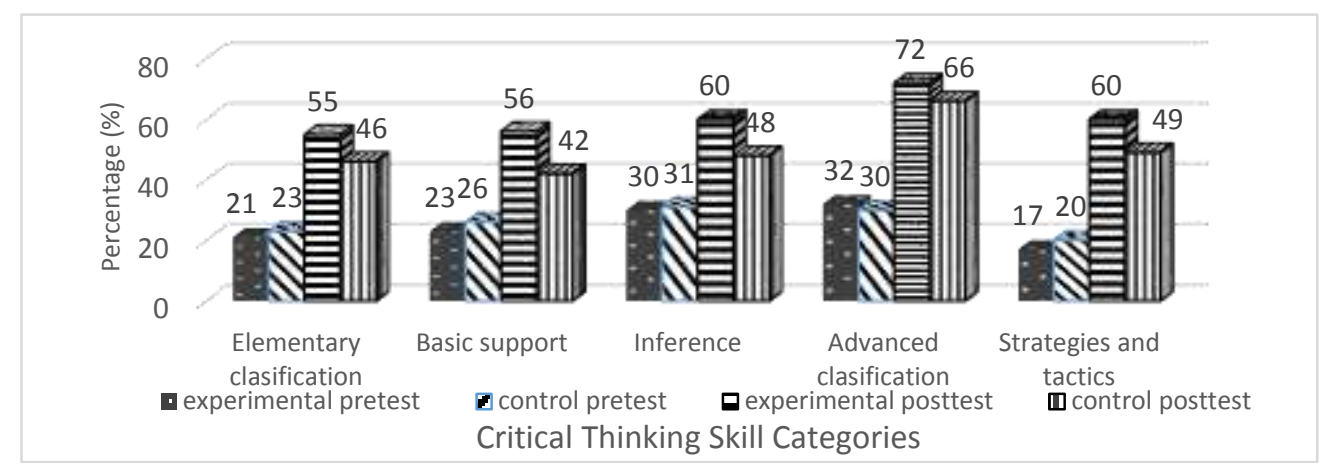

Fig. 1. Diagram Result of Pretest and Posttest Students' Critical Thinking Skill Categories on The Experiment and Control Class

According to Figure 1, it reveals the result of students' critical thinking that is not only experimental class but also controlled class doing the enhancement. Figure 1 shows that the highest enhancement of experimental class is the strategies and tactics category (43\%), while controlled class is advanced clasification category (36\%). Meanwhile, the lowest enhancement of experimental class and controlled class is the inference category (26\% and $11 \%)$. It shows that all the critical thinking skill categories of experimental class critical thinking skill is better than controlled class.

The result of normality test of pretest and posttest data can be seen on Table 2 :

Table 2. Result of Normality Test of Pretest and Posttest Data of Experimental class and Controlled class

\begin{tabular}{|c|c|c|c|c|}
\hline \multirow[b]{2}{*}{ Statistic } & \multicolumn{2}{|c|}{ Pretest } & \multicolumn{2}{|c|}{ Posttest } \\
\hline & Experimental Class & Control Class & $\begin{array}{c}\text { Experimental } \\
\text { Class }\end{array}$ & Control Class \\
\hline Df & 26 & 26 & 26 & 26 \\
\hline Sig.(2-tailed) & 0,443 & 0,005 & 0,059 & 0,153 \\
\hline Significance Level $(\alpha)$ & \multicolumn{2}{|c|}{0,05} & \multicolumn{2}{|c|}{0,05} \\
\hline Decision & $\begin{array}{c}\text { Data Are Not } \\
\text { Distributed } \\
\text { Normally }\end{array}$ & $\begin{array}{l}\text { Data Distributed } \\
\text { Normally }\end{array}$ & $\begin{array}{l}\text { Data Distributed } \\
\text { Normally }\end{array}$ & $\begin{array}{c}\text { Data } \\
\text { Distributed } \\
\text { Normally }\end{array}$ \\
\hline
\end{tabular}

Meanwhile, the result of homogeneity test can be seen on Table 3 :

Table 3. Result of Calculation Homogeneity Test of Pretest and Posttest Data of Experimental and Controlled Class

\begin{tabular}{ccc}
\hline Statistic & $\begin{array}{c}\text { Pretest of Experimental } \\
\text { Class and Controlled Class }\end{array}$ & $\begin{array}{c}\text { Posttest of Experimental Class } \\
\text { and Controlled Class }\end{array}$ \\
\hline Levene Statistic & 0,877 & 6,091
\end{tabular}




\begin{tabular}{ccc}
$\begin{array}{c}\text { Sig. (2-tailed) } \\
\text { Significance Level }(\alpha)\end{array}$ & 0,353 & 0,017 \\
\hline Decision & $\begin{array}{c}\text { The two classes are } \\
\text { homogenous }\end{array}$ & $\begin{array}{c}\text { The two classes are not } \\
\text { homogenous }\end{array}$ \\
\hline
\end{tabular}

After normality and homogeneity test, we gain the information that pretest data are not distributed normally and are having the same variant. Therefore, hypothesis test is being done by nonparametric statistical test with Mann Withney test. Meanwhile, there is the information that posttest data are distributed normally and has different variant, so the hypothesis test is being done by $t$ '-test. The result can be seen on Table 4 .

Table 4. Hypothesis Test of Pretest and Posttest Data of Experimental class and Controlled class

\begin{tabular}{ccc}
\hline Statistic & Pretest & Posttest \\
\hline Sig. (2-tailed) & 0,747 & 0,017 \\
Significance Level $(\alpha)$ & \multicolumn{2}{c}{0,05} \\
\hline Decision & $\mathbf{H}_{\mathbf{0}}$ accepted & $\mathbf{H}_{\mathbf{a}}$ accepted \\
\hline
\end{tabular}

Table 4 shows the result of pretest is Sig. (2-tailed) > significance level $(\alpha)$, so null hypothesis $\left(\mathrm{H}_{\mathrm{o}}\right)$ is accepted or alternative hypothesis $\left(\mathrm{H}_{\mathrm{a}}\right)$ is rejected. After accepting null hypothesis $\left(\mathrm{H}_{\mathrm{o}}\right)$, it can be concluded that before being given the treatment, we find no difference of the students' critical thinking skill of experimental and controlled class. The result of posttest is Sig. (2-tailed) < significance level $(\alpha)$, so the hypothesis $\left(H_{0}\right)$ is rejected and alternative hypothesis $\left(\mathrm{H}_{\mathrm{a}}\right)$ is accepted. After accepting alternative hypothesis $\left(\mathrm{H}_{\mathrm{a}}\right)$, it can be concluded that after being given the treatment, there are the difference of students' critical thinking skill of experimental and controlled class. It means that there is the effect of interactive multimedia base problem solving to the students' critical thinking skill.

The enhancement of students' critical thinking skill on every categories of critical thinking skill of experimental and controlled class can be seen on Table 5.

Table 5. The N-Gain Result of Pretest and Posttest of Experimental and Controlled Class

\begin{tabular}{|c|c|c|c|c|c|c|c|c|c|}
\hline \multirow[b]{2}{*}{ No } & \multirow{2}{*}{$\begin{array}{c}\text { Critical } \\
\text { Thinking } \\
\text { Categories }\end{array}$} & \multicolumn{4}{|c|}{ Experimental Class } & \multicolumn{4}{|c|}{ Controlled Class } \\
\hline & & $\begin{array}{c}\text { Score } \\
\text { Pretest }\end{array}$ & $\begin{array}{c}\text { Score } \\
\text { Posttest }\end{array}$ & $\begin{array}{c}N- \\
\text { Gain }\end{array}$ & Category & $\begin{array}{l}\text { Score } \\
\text { Pretest }\end{array}$ & $\begin{array}{c}\text { Score } \\
\text { Posttest }\end{array}$ & $\begin{array}{c}N- \\
\text { Gain }\end{array}$ & Category \\
\hline 1 & $\begin{array}{l}\text { Basic } \\
\text { Classification }\end{array}$ & 21 & 55 & 0,43 & Medium & 23 & 46 & 0,30 & Medium \\
\hline 2 & $\begin{array}{l}\text { Basic } \\
\text { Support }\end{array}$ & 23 & 56 & 0,43 & Medium & 26 & 42 & 0,22 & Low \\
\hline 3 & The Inference & 30 & 60 & 0,43 & Medium & 31 & 48 & 0,25 & Low \\
\hline 4 & $\begin{array}{l}\text { Advanced } \\
\text { Classification }\end{array}$ & 32 & 72 & 0,59 & Medium & 30 & 66 & 0,51 & Medium \\
\hline 5 & $\begin{array}{l}\text { Strategies } \\
\text { and Tactics }\end{array}$ & 17 & 20 & 0,52 & Medium & 20 & 49 & 0,36 & Medium \\
\hline
\end{tabular}

According to Table 5, it gains the information that there are the enhancement of critical thinking skill of experimental and controlled class. Every critical thinking skill categories has the enhancement by medium categorized in experimental class. Meanwhile, controlled class has the enhancement of two critical thinking skill categories in low category and three critical thinking skill categories in medium category. 
The students' response to the interactive multimedia base problem solving can be seen on result of data of questionnaire. The result calculation of data of questionnaire can be seen on Table 6.

Table 6. The Questionnaire Result of Students' Response of The Study Applying Multimedia Interactive Base Problem Solving

\begin{tabular}{clcc}
\hline No & \multicolumn{1}{c}{ Questionnaire Indicator } & Percentage & Category \\
\hline 1 & $\begin{array}{l}\text { The Presentation of Multimedia } \\
\text { Interactive Base Problem Solving }\end{array}$ & 84 & Very Good \\
& $\begin{array}{l}\text { The Effect of Multimedia Interactive } \\
\text { Base Problem Solving on Critical } \\
\text { Thinking Skill }\end{array}$ & 74 & Good \\
\hline & Average & $\mathbf{7 8}$ & Good \\
\hline
\end{tabular}

According to Table 6, it shows that the presentation of interactive multimedia base problem solving in good category. Furthermore, interactive multimedia base problem solving is in good category on enhancement of students' critical thinking skill. It means that the study that is applying interactive multimedia base problem solving gains a whole prositive response.

\subsection{Discussion}

Based on the research result that has been presented, the critical thinking skill of experimental class and controlled class are relatively same before doing the treatment. However, after the treatment, experimental class is better than controlled class. Moreover, based on hypothesis test of posttest is gained Sig. (2-tailed) > significance level $(\alpha)$. It means that applying interactive multimedia base problem solving affects students' critical thinking skill. According to [14], this is in line with the result of the research that the average score of the students with interactive multimedia is better than the student with the conventional learning. According to [8] [9] it shows that the average score of the student with problem solving learning is better than the student with the conventional learning. Meanwhile, based on the $N$-Gain result, the increase of students' critical thinking skills in experimental class is higher than controlled class. The increase puts on every categories, they are elementary classification, basic support, the inference, advanced classification, strategies and tactics.

The elementary classification categories in experimental class is better than controlled class because of the interactive multimedia base problem solving. It presents the video of the real life problem (understanding step), with result that student can analyze the presented problem. To guide students in analyzing problem relate to the real life can increase elementary classification skill [15].

The basic support categories in experimental class is higher than controlled class because of interactive multimedia base problem solving that facilitates students to do the simulation, reading material learning, and watching video that is presented on planning step. On the planning step, students are being led to be active and independent to discover the information. Discovering information by their own enhance the basic support skill [16].

The critical thinking skill of experimental class is better than controlled class on inference categories. This is because interactive multimedia base problem solving that is being facilitated the box to draw the conclusion to solve the problem (checking step). Drawing conclusion based on problem solving enhances skill of inference [17] [18].

Experimental class enhances critical thinking skill which is higher than controlled class on advance classification categories. Interactive multimedia base problem solving guides 
students to explore the material learning through the simulation that is presented on planning step. Simulation guides students to discover the relation among variable of a concept. By finding the relation of variable, students can draw conclusion of learning material. Therefore, students can defining term and judging definitions. Defining term and judging definitions enhancing the advanced classification skill [19].

On strategies and tactics categories, experimental class is better than controlled class. This is because interactive multimedia is designed by applying the steps of problem solving model that is drilled the students to solve the problem. Solving problem process can drill the strategies and tactics skill [20].

Interactive multimedia base problem solving has not only the advantages which is mentioned above but the weaknesses that have been found in the learning process. First, the limitation of throwing the evaluation feedback. As a result, the students do not know whether their answers right or wrong. Second, interactive multimedia base problem solving is not online for keeping the students' answer. So that, the answer will be saved in only the same computer. If they change the computer, the answer will loss. However, the application of interactive multimedia base problem solving in learning process enhances the students' critical thinking skill and gains the positive response. Therefore, interactive multimedia base problem solving can be alternative media to solve the problem of the low students' critical thinking skill in equilibrium and rotational dynamics concept.

\section{Conclusion}

Based on the result of research, it can be concluded that the study by applying interactive multimedia base problem solving has the significant effect on students' critical thinking skill in equilibrium and rotational dynamics concept. It can be seen on the result of statistical hypothesis test of posttest that shows Sig. 2 -tailed $(0,017)<$ significant level $(0,05)$. Moreover, the result of $\mathrm{N}$-Gain shows that experimental class enhances their critical thinking skill which is higher than controlled class on every indicator by medium category. The students' response of the learning by applying interactive multimedia base problem solving is in good category $(78 \%)$.

Acknowledgements. Finally we thank the administrative staff of Syarif Hidayatullah State Islamic University Jakarta, supervisor lecturers, teachers at Al-Qur'aniyyah Integrated Islamic Senior High School, and students who have participated in this research.

\section{Reference}

[1] I. Rahmawati, S. Sutopo, and S. Zulaikah, "Analysis of students' difficulties about rotational dynamics based on resource theory," J. Pendidik. IPA Indones., vol. 6, no. 1, pp. 95-102, 2017.

[2] R. H. Ennis, "The Nature of Critical Thinking: An Outline of Critical Thinking Dispositions," pp. 1-8, 2011.

[3] D. Fitria Wulandari, I. Hamidah, and A. Setiawan, "Physics of Learning Strategy to Train Critical and Creative Thinking Skills," Int. J. Sci. Res. ISSN (Online Impact Factor, vol. 3, no. 11, pp. 2319-7064, 2012.

[4] D. S. Asysyifa, J. Jumadi, I. Wilujeng, and H. Kuswanto, "Analysis of Students Critical Thinking Skills Using Partial Credit Models (PCM) in Physics Learning," Int. J. Educ. Res. Rev., vol. 4, no. 2, pp. 245-253, 2019.

[5] S. Mishra and R. C. Sharma, Interactive Multimedia in Education and Training. 
United State of America: Idea Group Publishing, 2005.

[6] M. F. Amir, F. N. Hasanah, and H. Musthofa, "Interactive multimedia based mathematics problem solving to develop students' reasoning," Int. J. Eng. Technol., vol. 7, no. 2.14, pp. 272-276, 2018.

[7] A. Kristiyono, "BERBASIS PROBLEM SOLVING," Universitas Muhammadiyah Surakarta, 2016.

[8] B. Umar, B. Jatmiko, and R. Raharjo, "Contextual Approach Using Problem Solving Model To Improve,” vol. 7, no. 2, pp. 1501-1505, 2018.

[9] B. Utami, S. Probosari, Riezky MayaSaputro, A. Ashadi, M. Masykuri, and A. Sutanto, "Students' critical thinking skills profile: constructing best strategy in teaching chemistry," IJPTE Int. J. Pedagog. Teach. Educ., vol. 2, no. January, pp. 71-76, 2018.

[10] J. McMillan and S. Schumacher, Research in Education Evidence-Based Inquiry, no. Seventh Edition. Pearson Education, 2014.

[11] Sugiono, Metodologi Penelitian: Kuantitatif, Kualitatif, dan R\&D. Bandung: Alfabeta, 2015.

[12] R. H. Ennis, "A Logical Basis for Measuring Critical Thinking Skills," Educ. Leaderschip, vol. oktober, pp. 44-48, 1985.

[13] G. Polya, How To Solve It A New Aspect of Mathematical Method. Princeton University Press, 1945.

[14] B. Susanto and A. Suyatna, "Design Learning Media of Global Warming Based on Interactive Multimedia With Scientific Approach to Improve Critical Thinking Skills," in Proceeding the 3rd SEA-DR, 2015, pp. 325-334.

[15] F. Amaniyah, "Pengaruh Model Pembelajaran Sains Teknologi Masyarakat Terhadap Keterampilan Berpikir Kritis Siswa pada Konsep Archaebacteria dan Eubacteria," Universitas Islam Negeri Syarif Hidayatullah Jakarta, 2015.

[16] S. Yeritia, W. Wahyudi, and S. Rahayu, "Pengaruh Model Pembelajaran Inkuiri Terbimbing Terhadap Penguasaan Konsep Dan Kemampuan Berpikir Kritis Fisika Peserta Didik Kelas X SMAN 1 Kuripan Tahun Ajaran 2017/2018,” J. Pendidik. Fis. dan Teknol., vol. 3, no. 2, pp. 181-187, 2017.

[17] A. Muhlisin, H. Susilo, M. Amin, and F. Rohman, "Improving critical thinking skills of college students through RMS model for learning basic concepts in science," AsiaPacific Forum Sci. Learn. Teach., vol. 17, no. 1, pp. 1-36, 2016.

[18] J. E. Dowd, R. J. Thompson, L. A. Schiff, and J. A. Reynolds, "Understanding the Complex Relationship between Critical Thinking and Science Reasoning among Undergraduate Thesis Writers," CBE Life Sci. Educ., vol. 17, no. 4, pp. 1-10, 2018.

[19] Z. Agustia and Y. Azizahwati, "The Implementation of Hands on Activities for Improving Students' Critical Thinking Skill in Physics Learning of Junior High School Level," J. Online Mhs. Bid. Kegur. dan Ilmu Pendidik., vol. 3, no. 2, pp. 1-14, 2016.

[20] R. Rasiman, "Leveling of Students' Critical Ability in Solving Mathematics Problem Based on Gender Differences," Int. J. Educ. Res., vol. 3, no. 4, pp. 307-318, 2015.

[20] Rasiman. 2015. 'Leveling of Students' Critical Thinking Ability in Solving Matematics Problem Based on Gender Differences". International Journal of Education and Research, vol. 3 (4). 307-318. 